\title{
Decomposition of Fructosan by the Timothy Leaf Spot Fungus, Cladosporium phlei
}

\author{
Yôsuke Mino* and Ryutaro SAKAI* \\ 美濃羊輔*・酒井隆太郎* : チモシー斑点病菌 Cladosporium phlei \\ によるフラクトサンの分解
}

\begin{abstract}
Two intracellular and an extracellular $\beta$-fructof ranosidases (E. C. $\# 3.2 .1 .26$ ) (Int I, Int II and Ext I) were obtained from the timothy leaf spot fungus, Cladosporium phlei and the culture filtrate, respectively, by DEAE Sephadex A-50 column chromatography. All these enzymes hydrolysed sucrose, raffinose and $\beta-2,6$-fructosan (prepared from the timothy haplocorm), but were incapable of hydrolyzing inulin and methyl- $\alpha$-Dglucoside. Only Ext I showed higher affinity to $\beta$-2,6-fructosan than to sucrose, differing from the two intracellular enzymes. The optimum pHs of Int I, Int II and Ext I were 5.0, 5.0 and 5.5, respectively, regardless of the substrates tested. Ext I was relatively heat stable as compared with Int I and Int II.
\end{abstract}

(Received August 7, 1979)

\section{Introduction}

Timothy leaf spot disease is the most serious foliar disease of timothy in Hokkaido. The causal organism of the leaf spot is Cladosporium phlei. Timothy contains a considerable amount of $\beta$-2,6-fructosan, instead of starch, in the leaves as well as the haplocorms ${ }^{8)}$. Availability of this fructosan as a carbon source by this fungus is therefore considered to be important in relation to its parasitism. Many workers ${ }^{1,5,9)}$ have reported the production of the enzymes involved in starch degradation by various phytopathogenic fungi. On the other hand, several investigators $2,3,4,6,10)$ have described the adaptive formation of fructosanases by microbes using inulin ( $\beta-2,1$-fructosan) or levan $(\beta-2,6$-fructosan of microbial origin), but no evidence has been published showing that $\beta$-2,6-fructosan from higher plants (phlein) can be decomposed by phytopathogenic fungi. The present study deals with the degradation of this fructose polymer by $C$. phlei.

\section{Materials and Methods}

Fungal culture. A pathogenic isolate of Cladosporium phlei de Vries was isolated from an infected local variety of timothy (Phleum pratense L.) located in Tokachi district in 1969. The stock culture was maintained on the medium of potatoglucose slant at $25 \mathrm{C}$ in the dark for a month. From this stock culture, a loopful of the fungus was inoculated into a $500 \mathrm{ml}$ Erlenmeyer flask containing $250 \mathrm{ml}$ of potato extract medium including $2 \%$ sucrose and cultured without shaking at $25 \mathrm{C}$ for 3

* Obihiro University of Agriculture and Veterinary Medicine, Hokkaido 080, Japan 带広畜産大学環境植物学研究室 
weeks. The cultured fungus was washed with distilled water. After removing excess water on the surface with filter papers, the fungus was used for the enzyme preparation.

Enzyme preparation. Thirty grams (fr. wt.) of the fungus were homogenized in $100 \mathrm{ml}$ of Tris- $\mathrm{HCl}$ buffer $(50 \mathrm{mM}, \mathrm{pH} 7.2)$ with $5 \mathrm{~g}$ of quartz sand in a chilled mortar. The homogenate was centrifuged at $12,000 \times \mathrm{g}$ for $10 \mathrm{~min}$. To the supernatant was added solid ammonium sulfate up to $70 \%$ saturation. The precipitate formed was collected by centrifugation at $10,000 \times g$ for $5 \mathrm{~min}$ and then dissolved in the Tris-HCl buffer for the dialysis against tap water over night. The dialysate, from which the precipitate produced was previously centrifuged off, was concentrated to about $2 \mathrm{ml}$ under reduced pressure using a collodion bag. This crude enzyme solution underwent column chromatography. The crude enzyme solution was also prepared from the culture filtrate (1 liter), which was previously centrifuged at $12,000 \times \mathrm{g}$ for $10 \mathrm{~min}$, by the same procedure as described for the case of the fungus.

Column chromatography. The above concentrated enzyme solution was chromatographed on DEAE SephadexrA-50 column. The column $(2.2 \mathrm{~cm} \times 15 \mathrm{~cm})$ was eluted stepwise with Tris- $\mathrm{HCl}$ buffer $(50 \mathrm{mM}, \mathrm{pH} 7.2)$ containing different amounts of $\mathrm{NaCl}$ at the flow rate of $30 \mathrm{ml} / \mathrm{hr}$. The eluate was collected in $8 \mathrm{ml}$-fraction.

Assays of the enzyme activities. The reaction mixture consisted of $2 \mathrm{ml}$ of McIlvain buffer ( $\mathrm{pH} 5.0$ ), and $1 \mathrm{ml}$ of each $1 \%$ sucrose or $\beta$-2,6-fructosan and enzyme solution. The mixture was incubated at $25 \mathrm{C}$ for $2 \mathrm{hr}$ and then adjusted to pH 7.0 with $1 \mathrm{~N} \mathrm{NaOH}$ solution to determine the amount of reducing sugars produced by the method of Somogyi-Nelson ${ }^{11}$ ) using a spectrophotometer (Shimazu UV140). Protein concentration was expressed as the absorbance at $280 \mathrm{~nm}$. $\beta-2,6$-Fructosan was prepared from the haplocorm of timothy as described previously ${ }^{7)}$.

Heat treatment. The enzyme solution was heated at designed temperature for $3 \mathrm{~min}$ in a water bath and then promptly cooled by running tap water.

\section{Results}

\section{Fractionation of the enzymes}

As shown in Fig. 1, two intracellular (Int I and Int II) and an extracellular (Ext I) sucrose hydrolases were fractionated from the fungus and the culture filtrate, respectively, by DEAE Sephadex A-50 column chromatography

\section{Substrate specificity}

Int I, Int II and Ext I hydrolysed raffinose and $\beta$-2,6-fructosan, in addition to sucrose, but were inactive to inulin and methyl- $\alpha$-D-glucoside. This suggests that these enzymes are $\beta$-fructofranosidase. Only Ext I showed higher affinity to $\beta$ 2,6 -fructosan than to sucrose.

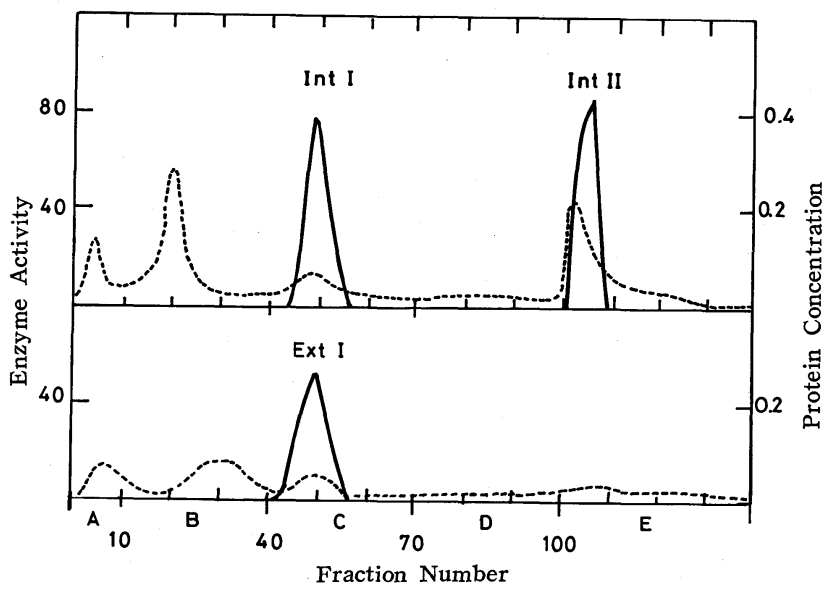

Fig.1. Elution profiles of protein (broken line) and enzyme activity (solid line) after DEAE Sephadex A-50 column chromatography. The enzyme activity is expressed as the amount of reducing sugars $(\mu \mathrm{g})$ produced from sucrose by $1 \mathrm{ml}$ of the reaction mixture. $\mathrm{A}$ is Tris- $\mathrm{HCl}$ buffer $(\mathrm{pH} 7.2,0.05 \mathrm{M}) . \mathrm{B}, \mathrm{C}, \mathrm{D}$ and $\mathrm{E}$ are A containing $0.1,0.2,0.3$ and $0.4 \mathrm{M} \mathrm{NaCl}$, respectively. 
Table 1. Substrate specificity

\begin{tabular}{l|r|r|r}
\hline \hline \multicolumn{1}{c|}{ Substrate } & \multicolumn{1}{c|}{ Int I } & Int II & Ext I \\
\hline Sucrose & $32(100)$ & $40(100)$ & $23(100)$ \\
Raffinose & $8(25)$ & $11(28)$ & $5(22)$ \\
$\beta-2,6-F r u c t o s a n$ & $6(19)$ & $6(15)$ & $34(148)$ \\
Inulin & 0 & 0 & 0 \\
Methyl- $\alpha$-D-glucoside & 0 & 0 & 0 \\
\hline
\end{tabular}

Figures given indicate reducing sugars $(\mu \mathrm{g})$ formed per $1 \mathrm{ml}$ of the reaction mixture and those in parentheses relative values to sucrose hydrolyzing activity(100).
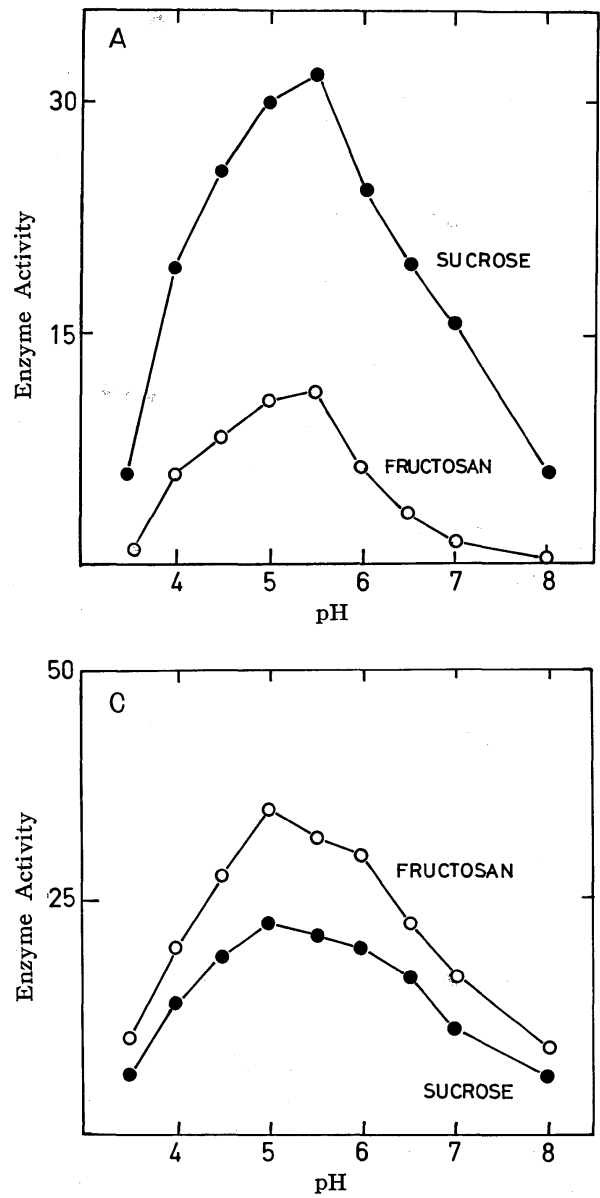

Effect of $p H$ on the enzyme activities

Effect of $\mathrm{pH}$ on the enzyme activities was examined using McIlvain Citrate buffer of different pHs. As shown in Figs. 2-A, B and $\mathrm{C}$, the optimum $\mathrm{pHs}$ of Int I, Int II and Ext I were around 5.0, 5.0 and 5.5 , respectively, regardless of the substrates tested. The $\mathrm{pH}$ activity curve of each fraction suggests that sucrose and $\beta-2,6$-fructosan are hydrolysed by the same enzyme.

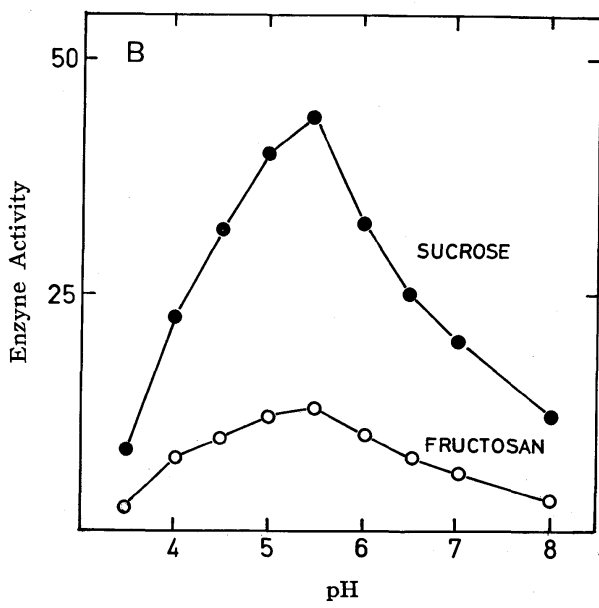

Fig. 2-A, -B and-C. The $\mathrm{pH}$ activity curves of Int I, Int II and Ext I. Open and closed circles indicate fructosan and sucrose hydrolysing activities, respectively.

\section{Effect of heat treatment}

Further experiments were carried out to examine the identity of sucrose and $\beta$-2,6-fructosan hydrolysing activities (SHA and FHA) (Table 2). The ratio of SHA to FHA was little altered by heat treatment at different temperatures irrespective of the enzyme sources. This supports again that hydrolysis of sucrose and $\beta-2,6$ fructosan was exerted by the same enzymes. Ext I was relatively more heat stable as compared with two intracellular enzymes. 
Table 2. Effect of heat treatment on sucrose and fructosan hydrolysing activities

\begin{tabular}{c|r|r|r|r|r|r|r|r|r}
\hline \multirow{2}{*}{$\begin{array}{c}\text { Treatment } \\
\text { temp. C }\end{array}$} & \multicolumn{3}{|c|}{ Int I } & \multicolumn{3}{|c|}{ Int II } & \multicolumn{3}{c}{ Ext I } \\
\cline { 2 - 9 } & $\mathrm{S}$ & $\mathrm{F}$ & $\mathrm{S} / \mathrm{F}$ & $\mathrm{S}$ & $\mathrm{F}$ & $\mathrm{S} / \mathrm{F}$ & $\mathrm{S}$ & $\mathrm{F}$ & $\mathrm{S} / \mathrm{F}$ \\
\hline Untreated & 100 & 100 & 1.00 & 100 & 100 & 1.00 & 100 & 100 & 1.00 \\
40 & 100 & 100 & 1.00 & 100 & 100 & 1.00 & 105 & 100 & 1.05 \\
50 & 85 & 88 & 0.97 & 94 & 90 & 1.04 & 100 & 100 & 1.00 \\
60 & 44 & 50 & 0.88 & 46 & 45 & 1.02 & 68 & 70 & 0.97 \\
70 & 0 & 0 & & 0 & 0 & & 5 & 6 & 0.83 \\
\hline
\end{tabular}

The activity of untreated enzyme is expressed as $100 . \mathrm{S}$ and $\mathrm{F}$ indicate sucrose and fructosan, respectively.

\section{Discussion}

Two intracellular (Int I and Int II) and an extracellular (Ext I) enzymes capable of decomposing sucrose and $\beta$-2,6-fructosan were shown to be produced by $C$. phle $i$ (Fig. 1 and Table 1). Though Ext I was eluted in the same fraction volume as that in Int $\mathrm{I}$, they are assumed to be different from each other, from the comparisons of their $\mathrm{pH}$ activity curves (Figs. 2-A, B and C), sensitivity to temperature (Table 2) and substrate specificity (Table 1). There is however a possibility that the configuration of the enzyme molecule (Int I) once formed in the cell is modified in the process of its releasing or in the culture medium.

Each fraction (Int I, Int II and Ext I) showed an ability to decompose both sucrose and $\beta$-2,6-fructosan (Table 1). These two saccharides are considered to be attacked by the same enzyme from the similarity of $\mathrm{pH}$ activity curves between sucrose and $\beta$-2,6-fructosan (Figs. 2-A, B and C) and the invariability of $\mathrm{S} / \mathrm{F}$ by treatment at different temperatures (Table 2). Though some microorganisms have been reported to produce inulinase ${ }^{6)}$, the enzyme from $C$. phlei and its culture medium were all inactive to inulin. Using the enzymes from Azotobacter chroococcum Hestrin and Goldblum ${ }^{3)}$ demonstrated that levan ( $\beta-2,6$-fructosan of microbial origin) was decomposed into oligolevan by levanpolyase (inactive to sucrose), which was further degraded into fructose by levanoligase. The enzymes prepared from $C$. phlei is therefore probably distinct from hitherto recognized fructofranosidase entities, since our enzymes were active to both sucrose and $\beta-2,6$-fructosan. In this study $\beta-2,6$-fructosan from a higher plant was used, instead of levan, so that this difference may be attributed to the kinds of substrates tested. These problems should be therefore clarified by the experiments on the decomposition patterns of various saccharides from different sources using the further purified enzymes.

Loewenberg and Reese ${ }^{6}$ ) reported that various microorganisms can produce adaptively fructosanase only in the presence of fructose ploymers such as inulin and levan. Contrary to this, $C$. phlei produced $\beta-2,6$-fructosan hydrolysing enzymes even in the absence of such fructosan. In view of the report that some fungi and bacteria have an ability to synthesize fructosan from sucrose ${ }^{6)}$, the induction of these enzymes by $C$. phle $i$ may be triggered by certain inducer formed from some saccharides (e. g. sucrose) contained in the culture medium used.

The fact that $\beta$-fructofranosidase having higher affinity to fructosan than to sucrose is excreted into the culture medium from $C$. phlei will suggest a possibility that this fungus may practically utilize this fructosan, together with sucrose, as carbon sources for the growth on the host leaves. Besides, it will be of interest to investigate whether or not the properties of the enzymes produced by pathogens are 
in any way concerned with the kinds of saccharides present in the host plants.

The authors wish to express deepest appreciation to Dr. T. Narita for kindly supplying an isolate of Cladosporium phlei.

\section{Literature cited}

1. Fischer, E. H. and de Montmillon, R. (1951). Helv. Chim. Acta. 34 : 1987-1994.

2. Hestrin, S., Feingold, S. D. and Avigad, G. (1956). Biochem. J. 64 : 340-351.

3. Hestrin, S. and Goldblum, J. (1953). Nature $172: 1046-1047$.

4. van Houte, J. and Jansen, H. M. (1968). Archs. oral. Biol. $13: 827-830$.

5. Leopold, H. and Starbanow, M. P. (1943). Biochem. Z. $314: 232-249$.

6. Loewenberg, J. R. and Reese, E. T. (1957). Can. J. Microbiol. 3 : 643-650.

7. Mino, Y. and Maeda, K. (1974). J. Japan. Grassl. Sci. $20: 6-10$.

8. Ojima, K. and Izawa, K. (1970). Ibid. $16: 112-118$.

9. Sakai, R. (1957). Ann. Phytopath. Soc. Japan $22: 134-138$.

10. Snyder, H. E. and Phaff, H. J. (1962). J. Biol. Chem. 237 : 2438-2441.

11. Somogyi, M. (1952). Ibid. $195:$ 19-23.

和 文 摘 要

$$
\text { チモシー斑点病菌 Cladosporium phlei によるフラクトサンの分解 }
$$

\section{美濃羊輔・酒井隆太郎}

DEAE Sephadex A-50 カラムクロマトグラフィにより, チモシー斑点病菌 Cladosporium phlei の 菌体内から 2 つの (Int I I IntII), さらに培養濾液から 1 つの (Ext I ) $\beta$-フラクトフラノシダーゼが分画

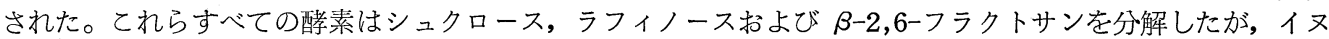

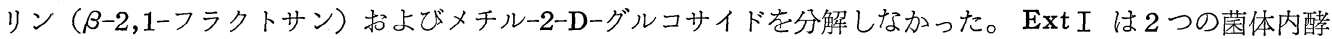
素と異なり，シュクロースよりも $\beta-2,6-$ フラクトサンを強く分解した。Int I, Int II および Ext I の至適 pH はそれぞれ 5.0，5.0，5.5であった。ExtＩ は2つの菌体内酵素に比して，わずかに熱安定性を示した。 チモシ一葉中にフラクトサンが含まれるととから，本菌によるその利用性が寄生性との 関連において論じら れた。 